\title{
The Political Integration of Immigrants: How Pre- and Postmigration Contexts Matter
}

\author{
Jörg Dollmann ${ }^{1,2}$ (1)
}

Accepted: 27 June 2021 / Published online: 26 July 2021

(c) The Author(s) 2021

\begin{abstract}
This study examines the political integration of immigrants in Germany and asks whether immigrants and their descendants show similar rates of political participation and expression of political attitudes as the population without an immigrant background. Furthermore, the study focusses on the pre- and postmigration context of immigrants and analyses whether immigrants differ in their level of political integration depending on (1) whether they come from more or less authoritarian regimes and (2) whether they have experienced discrimination in the receiving context. Using data from CILS4EU-DE, with a large representative sample of (children of) immigrants and non-immigrants in Germany, we observe differences in the political integration between immigrants and non-immigrants only on the attitudinal level, with immigrants showing lower levels of political trust but also slightly higher levels of satisfaction with the democratic system in Germany. When focussing on the effects of the pre- and the postmigration context, we observe differential results for the behavioural and attitudinal dimension: when immigrants stem from more authoritarian countries as well as when they have experienced more discrimination in the receiving context, this seems to mobilise respondents with respect to their political behaviour; however, it results in lower levels of political integration on the attitudinal dimension.
\end{abstract}

Keywords Political integration · Political participation · Political attitudes · Immigrants · Discrimination · Premigration context $\cdot$ Germany

Jörg Dollmann

joerg.dollmann@mzes.uni-mannheim.de

1 MZES - Mannheim Centre for European Social Research, University of Mannheim, Postfach 68131, Mannheim, Germany

2 German Centre for Integration and Migration Research (DeZIM), Berlin, Germany 


\section{Introduction}

Studies dealing with the integration of immigrants into their host societies focus mainly on the educational system and the labour market, which is not surprising given the importance of structural integration for the future life chances of individuals (Kalter, 2016). Other dimensions of integration have received little attention, such as the political one (c.f. Just \& Anderson, 2012: 482). However, studying whether how and why immigrants are politically active and integrated is crucial from at least two perspectives.

First, various forms of political participation enable immigrants to express their needs and demands (Bilodeau et al., 2010). Since political participation is the process through which relevant goals of a society are determined and appropriate measures to pursue these goals are chosen (Verba \& Nie, 1987: 4), unequal participation may result in a systematic underrepresentation of the interests of specific groups (De Rooij \& Eline, 2012). Second, political participation is an indicator of the degree of immigrants' integration and incorporation into their host societies as well as of their willingness to take part in civic life (Bevelander \& Pendakur, 2011; De Rooij \& Eline, 2012; Esser, 2015; Tillie, 2004). Immigrants' successful integration into the political systems of their receiving societies therefore contributes to the cohesion and systemic integration of the society (Bilodeau et al., 2010; Esser, 2015). Investigating ethnic differences in political integration is therefore crucial to our understanding not only of immigrants' representation in the political process and their influence on the political agenda, but also of the cohesion of the society as a whole.

Previous studies mainly focussed on the consequences of individual resources on political integration but often neglected two important macro conditions: the premigration and the postmigration context. Considering the premigration context seems particularly relevant because many immigrants all over the world leave authoritarian regimes to settle in mostly liberal democracies (Bilodeau et al., 2010). Given that many of these immigrants will obtain a long-term resident status and, after several years, may even acquire citizenship and the right to vote, it is a key question whether and how these people integrate themselves into the political system. Does the previous socialisation in an authoritarian regime have long-term consequences and hinder the political integration into the new, democratic receiving society? Or will immigrants adapt to the political culture of the receiving society and become an active part of it? Focussing on the postmigration context, we investigate whether the receiving society actually welcomes the (political) integration of immigrants or whether immigrants are facing conditions that discourage and prevent them from becoming politically active. More precisely, we ask whether discriminatory experiences in the receiving society prevent immigrants from integrating politically into their host societies or whether such experiences even encourage them to participate in political actions in order to change the system they perceive as unjust.

To answer these questions, we focus on the degree of political integration and its preconditions among a representative sample of 18 - to 20 -year-old youths with 
a direct (first generation) or indirect (second or third generation) migration background in Germany. In the following, we first look at the multidimensionality of political integration and describe the different aspects of this concept. We then outline why the level of political integration may differ between persons with and without immigrant background, focussing on possible long-term effects of socialisation in more or less liberal societies as well as of discriminatory experiences in the receiving society. After having introduced the data and described the variables used in the analyses, we present the results from different multivariate regression models and conclude with a discussion of these results.

\section{The Political Integration of Immigrants}

\section{Political Integration as a Multidimensional Construct}

Although there is scientific consensus that the concept of immigrants' political integration is multidimensional (e.g. Tillie, 2004), this does not apply to the number of dimensions and their content. To give structure to the vast variety of behaviours, beliefs and attitudes that are considered part of political integration, we here distinguish two superordinate dimensions of this broader concept: a behavioural dimension and an attitudinal dimension (see, for example, Eggert \& Giugni, 2010). ${ }^{1}$

Regarding the attitudinal dimension, several authors have declared political (but also generalised) trust as one important aspect of political integration (e.g. Tillie, 2004): people need to trust the political institutions and provide them with legitimacy in order to be politically integrated (Tillie, 2004). Furthermore, the adherence to democratic values is regarded as an important condition of political integration (Martiniello, 2006; Tillie, 2004): politically integrated people need to 'subscribe to the basic values of democracy' (Tillie, 2004: 530). Another important aspect of the attitudinal dimension of political integration is the subjective identification with the host society (Martiniello, 2006; Voicu \& Comşa, 2014).

On the behavioural dimension, the degree of political participation is often related to political integration (Martiniello, 2006). However, political participation is not a homogenous activity but comprises many different forms of activities, which are typically distinguished along two lines: the first differentiates between low-cost (e.g. signing a petition) and high-cost (e.g. actively supporting a party campaign) activities, the second asks whether an activity is conventional (e.g. voting) or unconventional (e.g. participation in demonstrations) (e.g. Barnes et al., 1979; De Rooij \& Eline, 2012; Lijphart, 1997). In addition, some authors refer to the importance of political interest in the process of political participation, 'inasmuch as one believes that those who are interested in politics are more likely to participate in some form of political action' (Bartram, 2019: 675). Finally, being involved in political

\footnotetext{
1 The aim of this study is to provide not a complete overview of all aspects that have so far been considered part of 'political integration' but a summary of the most prominent ones.
} 
discussions and active news consumption is considered another dimension of the behavioural aspect of political integration (e.g. Shingles, 1981).

This multidimensional structure of political integration makes it difficult to clearly define when an immigrant can be considered politically integrated. For example, a person who does not adhere to democratic values may be considered not politically integrated although he or she is integrated regarding one or more aspects of the behavioural dimension. In contrast, a person who trusts in the political institutions but shows little political interest may nevertheless be considered politically integrated. Therefore, we examine the level of political integration for the different aspects and subdimensions separately (cf. Tillie, 2004: 531).

\section{Explaining Differences in Political Integration Between Immigrants (and Their Descendants) and the Population Without an Immigrant Background}

\section{Standard Explanations for Political Integration}

Before shifting our focus to possible long-term effects of socialisation in an authoritarian regime and of discriminatory experiences in the receiving context on the level of immigrants' political integration, there are several other factors that need to be considered when examining why immigrant groups may differ in their degree of political integration. According to the seminal work by Verba and colleagues, systematic differences in the endowment with relevant resources or differences in the degree of integration into networks that recruit immigrants for political activities may contribute to disparities in political integration (e.g. Verba et al., 1993, 1995). For example, socioeconomically well-off persons are better equipped with monetary resources and are therefore more likely to support political activities, and persons that are more educated usually show higher levels of the relevant civic skills during their life course (Brady et al., 1995; Galston, 2001). Given that immigrants and refugees in Western Europe and Germany are likely to have a lower occupational status and educational level (Andritzky et al., 2016; Heath et al., 2008; Kristen \& Granato, 2007), these factors of socioeconomic background are especially important in explaining ethnic differences in political integration on both the behavioural and the attitudinal dimension.

Although explanations following a resource approach are important for our understanding of immigrants' political integration (Martinez, 2005), they may not be sufficient (Just \& Anderson, 2012). Immigrants may be disadvantaged not only with respect to their endowment with socioeconomic and educational resources, but also with respect to factors that are typically connected to immigrants' migration background. For example, skills in the language of the receiving country are essential to understand the functioning of the country's political system and therefore also to realise how and where political participation is possible (De Rooij \& Eline, 2012). Immigrants with lower language skills and lower levels of information may therefore be less inclined to participate in the political process and show less interest in the politics of the receiving country. 
Furthermore, immigrants may be more strongly connected to their own immigrant group and community and thus may show less interest in 'system-oriented' activities (Leighley \& Vedlitz, 1999: 1094-1095; c.f. also De Rooij \& Eline, 2012). This in turn may result in a lower participation of immigrants in political activities. Therefore, having more contact with other immigrants than with the non-migrant population - be it as friends or acquaintances - may be an obstacle to engaging in civic and political activities (e.g. Uslaner \& Conley, 2003).

Given the differences in endowment with relevant resources, the lower level of incorporation in non-migrant networks and the higher level of inclusion in ethnic networks, we expect that immigrants show a lower level of political integration on the different dimensions, irrespective of their country of origin. Following the idea that the endowment with relevant resources increases from generation to generation, we also expect higher levels of political integration in subsequent generations than in the first generation.

\section{The Premigration Context: How Socialisation in Less Liberal or Authoritarian Regimes May Affect the Political Integration of Immigrants}

Besides the endowment with relevant resources, also premigration experiences may affect immigrants' political interest or trust in political institutions, resulting in differential patterns of political engagement or (future) political participation. While modern, democratic countries with an open and competitive system of political participation strongly encourage people to engage in political actions, countries with authoritarian systems suppress political activities (Jaggers \& Gurr, 1995). Immigrants or refugees from countries with authoritarian regimes entering liberal receiving societies may not expect that their voice is heard and may have less trust in political institutions based on their previous experience of futile attempts in the sending country. Consequently, they may also be less interested in political activities.

When investigating patterns of political integration of immigrants from authoritarian regimes in Western democracies, a key question-particularly for this contribution-is whether (previous) socialisation experiences continue to have an effect after migration from repressive to more liberal societies (Bilodeau et al., 2010). In general, there are two main perspectives regarding this problem. On the one hand, scholars argue that political socialisation starts early in the life course and leads to the formation of specific values and orientations that are comparably stable and less likely to be changed in later life (e.g. Bilodeau et al., 2010; Voicu \& Comşa, 2014; White et al., 2008). This persistence perspective argues that immigrants from countries in which political participation is not supported or even suppressed will most probably abstain from political actions also in the host society. Supporting this perspective, Bilodeau (2008) reports findings which show that the degree of political repression in the sending context goes hand in hand with immigrants' level of abstinence from protest politics in the receiving context.

In contrast to this classical political socialisation approach, another perspective emphasises the possibility of resocialisation and argues that political values and beliefs are subject to change throughout the life course (Bilodeau et al., 2010; White et al., 2008). Within this theoretical strand, the theory of exposure regards 
immigrants as almost 'tabula rasa' once they arrive in a new receiving country (White et al., 2008: 270). In contrast, the transferability theory takes prior experiences of immigrants into account and argues that these experiences can be applied to and used in the new environment of the receiving society (Voicu \& Comşa, 2014; White et al., 2008). Therefore, and although political participation was suppressed prior to migration, immigrants from authoritarian regimes may adapt to the new conditions and can, depending on the time of exposure, assimilate to the participation patterns of immigrants from more democratic societies. Furthermore, it is even possible that immigrants from countries with oppressive political systems become even more politically active and integrated, as they gain possibilities and freedom they did not have before (Bilodeau, 2008: 977).

These theories mainly apply to immigrants from the first generation, who were socialised in their sending countries. In contrast, second- and third-generation immigrants have been socialised in the context of the receiving country. However, they too can be influenced by the socialisation experiences of their parents: it has been repeatedly shown that political socialisation starts quite early in the life course and that the family plays an important role in the development of political behaviour (Jennings et al., 2009; McFarland \& Thomas, 2006; Verba et al., 1995). If it is actually the case that premigration experiences matter for immigrants' political participation, they may also matter for the socialisation of immigrants' children. Following this argument, not only immigrants but also children of immigrants may be influenced by authoritarian regimes of their country of origin. For example, even after decades in the new receiving society, immigrants' beliefs about other acceptable governmental forms next to democracy (Bilodeau et al., 2010) may be transmitted to their children, and this transmission may be at least partly independent of the actual context they are living in (Wong \& Tseng, 2008). Patterns of political participation that (partly) do not follow the general assumptions of straight-line assimilation, with no complete adaption of political participation rates to those of the native population over generations, may be examples for such lasting effects of different regimes in the sending country (e.g. Logan et al., 2012; Ramakrishnan \& Espenshade, 2001).

The above considerations lead us two concurring hypotheses: Following the persistence perspective, we assume that immigrants from authoritarian regimes show lower levels of political integration in terms of both their attitudes and their behaviour (H1a). However, if the resocialisation perspective holds true, immigrants from authoritarian countries should be able to adapt to the new societies and their level of political integration should not differ from that of immigrants from other, more liberal countries $(\mathrm{H} 1 \mathrm{~b})$.

\section{The Postmigration Context: How Perceived Discrimination May Affect Immigrants' Political Integration}

Not only the premigration context may matter for immigrants' political integration, but also the postmigration context. The legislation of a country and its institutional framework that defines who is eligible to vote (e.g. citizens or non-citizens) is a prime example of how national regulations in the receiving context may affect immigrants' possibilities to take political action (Just \& Anderson, 2014). However, 
also the general socio-political (e.g. less liberal or open) context of a receiving society may affect immigrants' political integration (Just \& Anderson, 2014). In many Western European countries, and also in Germany, many citizens have negative attitudes towards immigrants (Semyonov et al., 2004). Furthermore, discrimination has been proved to exist in various domains of life in Germany, for example in the housing market (Horr et al., 2018), the vocational training system or the labour market (Kaas \& Manger, 2012) as well as in the sharing economy (Liebe \& Beyer, 2020).

How does such discriminatory behaviour affect the political integration of immigrants? In the literature, two different arguments are presented. On the one hand, discrimination against immigrants may lead to some kind of depoliticisation (Fleischmann et al., 2011) and to lower degrees of political participation among immigrants experiencing such threats. For example, in the US context, Schildkraut (2005) reports that perceived discrimination promotes both behavioural and attitudinal alienation, leading to a higher risk of non-voting and to a lack of trust. Similar results have been reported for immigrants from Muslim origin in the French context (Adida et al., 2014).

On the other hand, discrimination and stigmatisation may also mobilise the political engagement of immigrants (Just \& Anderson, 2014; Ramakrishnan, 2005). Several studies have shown that the threat and discrimination a group perceives is causally and positively related to its level of political mobilisation and participation (Cho et al. 2006; Miller \& Krosnick, 2004, for a more comprehensive review, see Just $\&$ Anderson, 2014). For example, perceived or actual unjust and unfair behaviour towards immigrants or ethnic minorities may increase the probability to participate in demonstrations with the aim of changing the status quo and protesting against these political or societal developments (Just \& Anderson, 2014).

Again, we derive two concurring hypotheses from the considerations above. Following the depoliticisation perspective, we expect that respondents who experienced discrimination show lower levels of political integration $(\mathrm{H} 2 \mathrm{a})$. Following the mobilisation arguments that consider politisation as a reaction to discrimination, we assume that immigrants who experienced discrimination show higher levels of political integration $(\mathrm{H} 2 \mathrm{~b})$.

\section{Data and Methods}

\section{Data and Analytical Sample}

The analyses are based on the German part (CILS4EU-DE) of the Children of Immigrants Longitudinal Survey in Four European Countries (CILS4EU) (Kalter et al., 2016a, b, c, Kalter et al., 2017). The first wave of this panel study was conducted in the school year 2010/2011, with yearly follow-up waves. The respondents were selected on the basis of a three-stage sample design: First, schools were selected using a disproportionate stratified sampling strategy, with higher inclusion probabilities of schools with a higher share of immigrants. Additional implicit stratifiers guaranteed a proportional representation of schools according to school type and region. Within each sampled school, two classes were selected randomly, of which 
all students were asked to take part in the survey. The sampling process yielded a sample of 144 schools, 271 school classes and 5013 respondents (cf. CILS4EU, 2016a; Kalter et al., 2019).

The first two waves of CILS4EU were administered in the school context, and from wave 3 onwards personal interviews were conducted outside school using web, postal and telephone interviews. During wave 1, a parental interview was conducted (telephone or paper-pencil questionnaires), in which 78 per cent of the parents of respondents from wave 1 took part (CILS4EU, 2016a). Response rates in the different waves of the student survey vary between over 80 per cent in waves 1 and 2 (cf. CILS4EU, 2016a, b), 67 per cent in the wave 3 (c.f. CILS4EU, 2016c) and 80 and 86 per cent in waves 4 and 5, respectively (cf. Olszenka et al., 2016; Sauter et al., 2017). In total, 2817 respondents completed an interview in wave 5, which is the wave in which a political and social participation module was included in the questionnaire and which therefore serves as an important source of information for this study. Missing values due to unit nonresponse (panel attrition) as well as item nonresponse are treated by multiple imputation using Stata's mi-command (Royston, 2004). ${ }^{2}$ To achieve efficient point estimates and replicable standard errors, we imputed the missing data $\mathrm{m}=25$ times (cf. Von Hippel, 2018).

\section{Measures}

In the social and political participation module of wave 5 of CILS4EU-DE, different forms of political integration were assessed. On the behavioural dimension, one question asked about the participation in demonstrations and another enquired whether the respondent supported a party or a party member, e.g. during a campaign. All questions referred to the period of the preceding 12 months and could be answered with 'yes' or 'no'. On the attitudinal dimension, respondents were asked how strongly they trusted different actors and institutions in order to assess their political trust. ${ }^{3}$ The answers were (reversely) combined in a scale ranging from 1 to 4 , with higher values indicating a higher level of political and institutional trust (Cronbach's alpha =0.76). Respondents were also asked how satisfied they were with the democratic system of Germany, with answer categories ranging from 1 'not satisfied at all' to 10 'very satisfied'.

Respondents were categorised as first-, second- or third-generation immigrants or as respondents without immigrant background (cf. Dollmann et al., 2014 for more information on the classification of immigrants). Furthermore, with the aim of testing possible long-term effects of a direct or indirect socialisation under an authoritarian regime, the origin countries of respondents with an immigrant background

\footnotetext{
${ }^{2}$ We use a basic imputation model, representing the analytical models presented here (cf. Mustillo, 2012). The same weighting procedures were used in the imputation and in the analytical model.

3 Five different questions: 'How strongly do you trust the following institutions or groups of persons? Political parties, courts, the police, politicians, the media (newspapers, television, radio).' Answer categories: 'very strongly', 'fairly strongly', 'not very strongly', and 'not at all strongly'.
} 
were classified according to the Democracy Index 2014 (Economist Intelligence Unit, 2015), because this was the year preceding the fifth wave of CILS4EU-DE data collection. ${ }^{4}$ However, the classification is relatively stable over time; i.e., the scores differ only marginally between different years. The index ranges from 1.08 (North Korea) to 9.93 (Norway), with higher scores indicating more liberal societies.

Perceived discrimination was measured in the first and third waves of CILS4EU, i.e. when respondents were aged around 15 and 17 , respectively, focusing on different domains of life. More precisely, in each wave, students were asked whether they felt discriminated or treated unfairly in (i) school; (ii) trains, buses, trams or subways; (iii) shops, stores, cafés, restaurants or nightclubs; and (iv) by the police or security guards (answer options were 'always', 'often', 'sometimes' and 'never'). The answers were combined in a scale ranging from 1 to 4 (Cronbach's alpha =0.64), with higher values indicating lower levels of perceived discrimination.

Following the theoretical considerations, differences between immigrants and nonimmigrants but also within the immigrant group may be due not only to differences in socialisation contexts and perceived discrimination in the receiving context, but also to differences in important background characteristics. To account for these differences, we consider the highest ISEI (International Socio-Economic Index of Occupational Status) score in the family as a measure of respondents' social background. Furthermore, we include students' educational background, measured by the school track they attended during the first wave (academic track [Gymnasium]; lower and upper vocational tracks [Haupt- and Realschulen]; schools combining several tracks; schools for special needs). ${ }^{5}$ We also include respondents' grades in German and math in the analyses, together with cognitive test scores from a language-free and culturally fair cognitive ability test (CFT 20: Weiß, 1998). Economic resources in the family are measured by asking respondents about their ability to raise a specific amount of money by tomorrow (existence of a 'cash margin'; answer categories 'no', 'yes' and 'don't know'; the latter two categories are combined in the multivariate analyses). To assess differences in social integration, we include questions about club attendance in waves 1,2 and $3^{6}$ and combine the answers in one scale ranging from 1 to 5 (Cronbach's alpha=0.79), with higher values representing higher participation rates in these clubs.

Language skills as one specific ethnic resource are taken from an objective language test (Heller \& Perleth, 2000) that was also carried out during the first wave

\footnotetext{
${ }^{4}$ In order to match the respondents' countries of origin to the countries listed in the Democracy Index, we use the variable indicating the respondent's country of origin as provided in the CILS4EU-data (' $y 1_{-}$ countorigG' or 'countorigG' in Dollmann et al., 2014). This variable is constructed by considering all countries of birth besides Germany of each actor being part of the respective 'three generation-cluster' (ego, mother of ego, father of ego, mother of mother of ego, father of mother of ego, mother of father of ego, father of father of ego; for more information: Dollmann et al., 2014).

${ }^{5}$ In the analyses, the very few students from schools for special needs are grouped into the lowest track (lower vocational track). Results do not change substantially when these students are excluded from the analyses. It is not feasible to include a separate category for 'school for special needs' due to the low number of cases.

${ }^{6}$ Question: 'In your spare time, how often do you spend time in a sports/music/drama/other club?' Answer categories: 'never', 'less often than once or several times a month', 'once or several times a month', 'once or several times a week' and 'every day'.
} 
of the survey. While the aforementioned social integration indicator (club attendance) does not carry information about the clubs' composition with respect to the other members' immigrant background, we include a score derived from the network composition of respondents from wave 1 to wave 5 (Cronbach's alpha $=0.87$ ), ${ }^{7}$ with higher values meaning a higher proportion of native friends. In addition, we include an item indicating respondents' citizenship, which distinguishes between having only the German citizenship, the German citizenship and another citizenship, and only another citizenship. As additional controls, age in years (assessed in wave 1) and gender are included in the analyses.

Table 1 displays the descriptive findings of the first imputed dataset. While the number of cases is reported unweighted, the percentages are weighted in order to account for the different selection probabilities of schools with different shares of immigrants, as described in the previous section. Focussing on the political integration on the behavioural dimension, we observe slightly higher rates for participation in demonstrations (especially for the first and the second generation; however, these differences are not statistically significant) but not for support of party campaigns. In contrast, we observe slightly lower rates of political trust and slightly higher levels of satisfaction with the German democratic system among the first and the second generation. Although group differences are generally rather low or even non-existent, these heterogenous results underline the necessity to differentiate between different measures of political integration.

As the Democracy Index 2014 shows, most respondents from the first generation come from countries with higher levels of authoritarianism, while most second-generation immigrants have migrated from more liberal societies. Although this information is used in the multivariate analyses only for these two generational groups, we also show the Democracy Index for the third generation, which is even higher (i.e. respondents stemming from more liberal societies) than that of the second generation. It goes without saying that the score for respondents without an immigrant background corresponds to the Democracy Index for Germany.

Interestingly, we observe virtually no differences between respondents with and without an immigrant background regarding the Discrimination Index. Respondents of the first and the second generation report slightly higher scores on this index, but only at the second decimal, which is why this result is not displayed here.

Regarding possible controls, immigrants on average have a lower social background and more often attend lower educational tracks during the first wave of the survey. We also observe this pattern of educational disadvantage with regard to scholastic achievement. Furthermore, respondents with an immigrant background less frequently attend clubs and have fewer German friends.

\footnotetext{
7 Question: 'How many of your friends have a German background?' Answer categories: 'almost all or all', 'a lot', 'about half', 'a few' and 'none or very few'.
} 


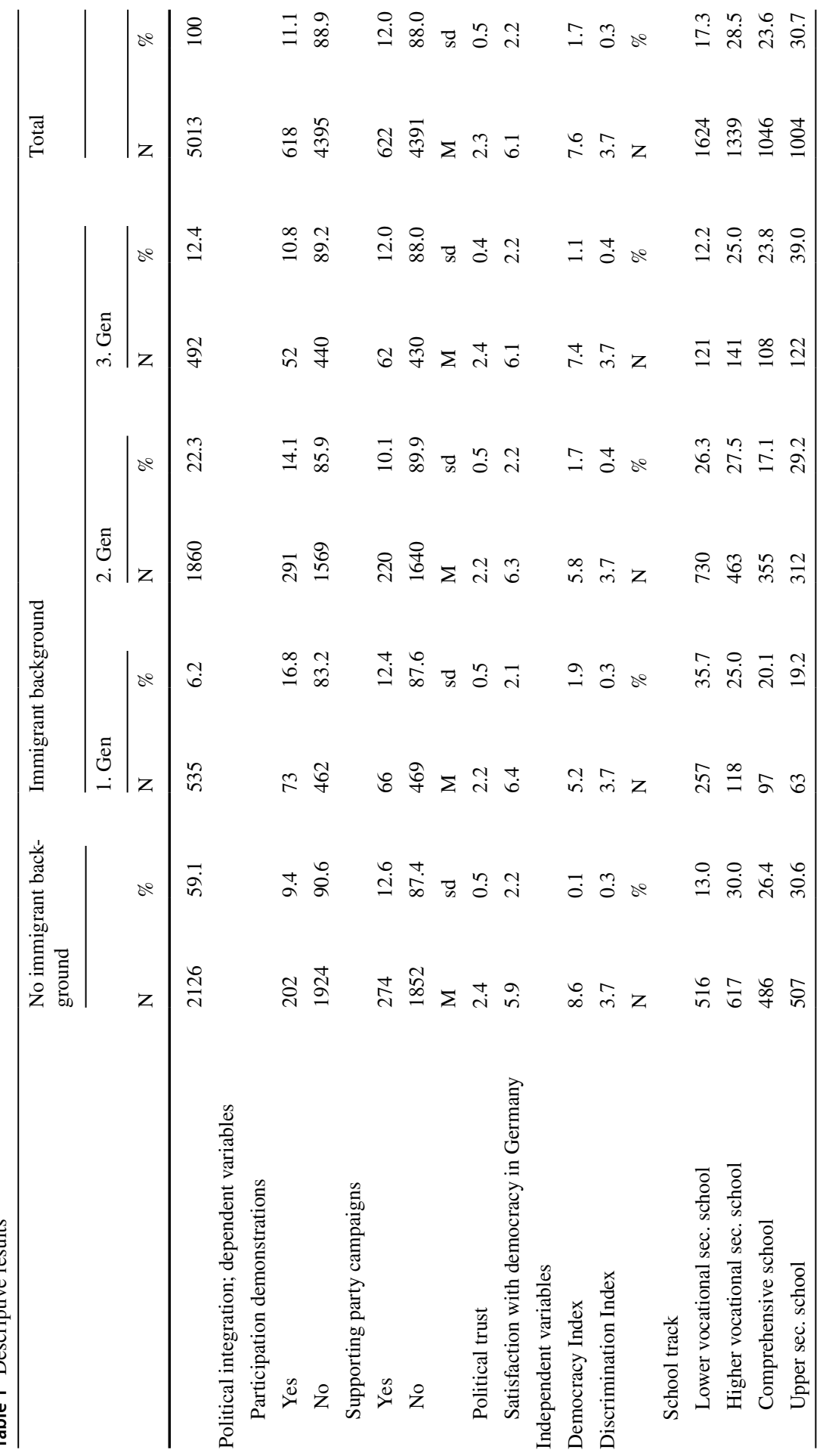




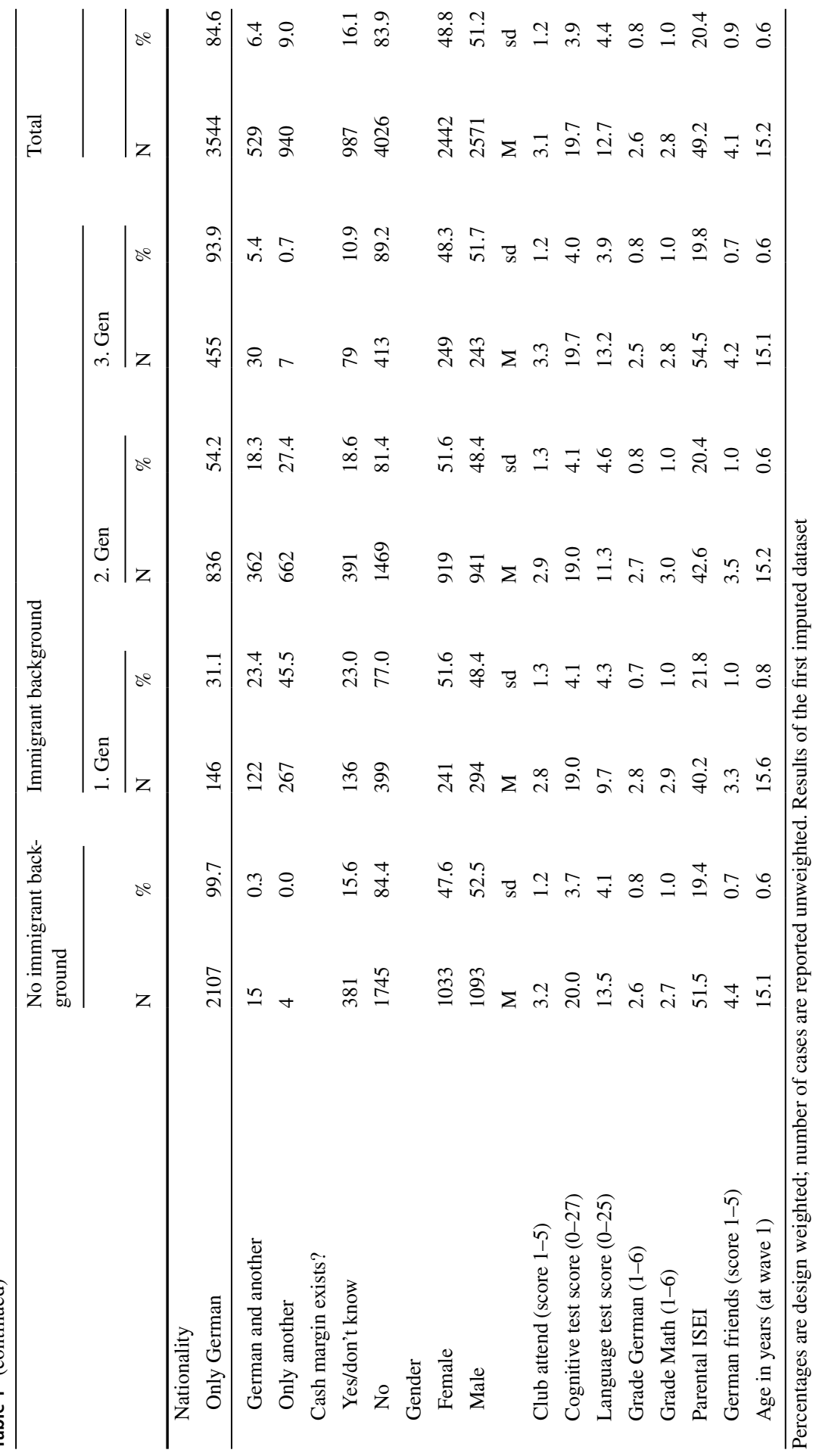




\section{Results}

In the subsequent analyses, we follow the recommendation by van Hippel and delete the cases with missing values in the dependent variables from the analyses, although they were used for the general multiple imputation procedure (Von Hippel, 2007). Cases with missing values on the independent variables are used in the analyses with their (combined) imputed values from the different imputed datasets. The procedure of deleting cases with missing values on the dependent variable results in a differing number of cases between the analyses depending on the construct under study. In the following multivariate analyses, we estimate ordinary least squares (OLS) regression models for the metric outcomes 'political trust' and 'satisfaction in the democratic system of Germany' and linear probability models (LPM) for the binary outcome variables 'participation in demonstrations' and 'support of party campaigns (for a discussion of the advantages of linear probability models over logistic regression models, see Mood, 2010). We first replicate the different patterns of political integration of respondents with and without an immigrant background, as reported in the descriptive results in Table 1. In doing so, we differentiate between immigrants from the first, second and third generation. In a second model, we ask whether these differences-if any-may be due to differences in the level of authoritarianism or liberalism of the different countries of origin. In a third model, we ask whether differences in perceived discrimination can account for differences in political integration-if any. Finally, in the two last models, we investigate whether these relationships still hold when including differences in endowment with resources, social background, nationality, language skills, attendance of clubs or other social activities, and network composition. This strategy is applied to each of the four dependent variables studied.

In line with the descriptive findings, the results from the first model in Tables 2 and 3 show that there are no statistically significant differences between respondents with and without an immigrant background regarding the two forms of political participation, i.e. participation in demonstrations and support of a party candidate or party campaign. However, respondents stemming from more liberal societies show lower levels of political participation with regard to both aspects of political participation studied (model 2). Furthermore, having perceived discrimination (model 3) seems to have a mobilising character, as respondents with a lower level of perceived discrimination show significantly lower levels of political participation, especially regarding participation in demonstrations. Both the mobilising effect of being socialised in a less liberal country and the mobilising effect of perceived discrimination remain once controlling for several individuallevel characteristics in models 4 and 5 .

As for political attitudes, and here political or institutionalised trust as well as satisfaction with the democracy in Germany, a different picture emerges. First, respondents of the first and second generation show lower levels of political trust (model 1, Table 4). In contrast, immigrants-and especially the first generationare slightly more satisfied with the democracy in Germany than respondents without an immigrant background (model 1, Table 5). With regard to the influence of the pre- and postmigration context, we observe fundamentally different results for 


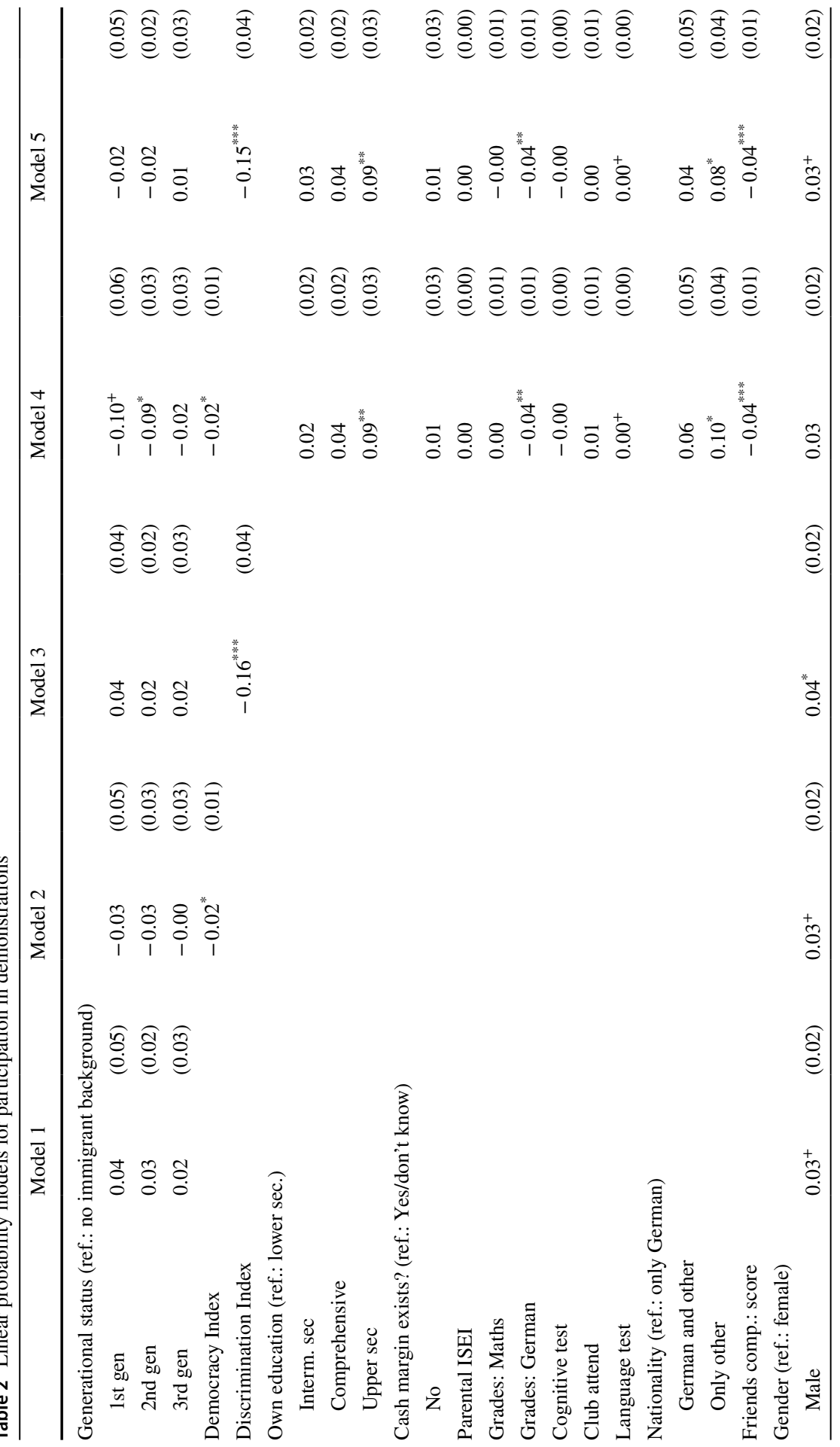




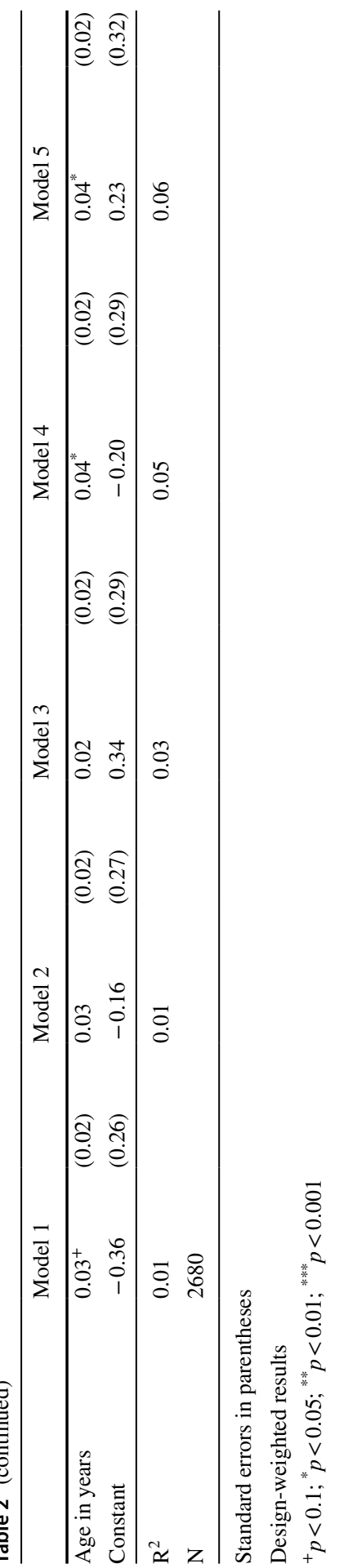




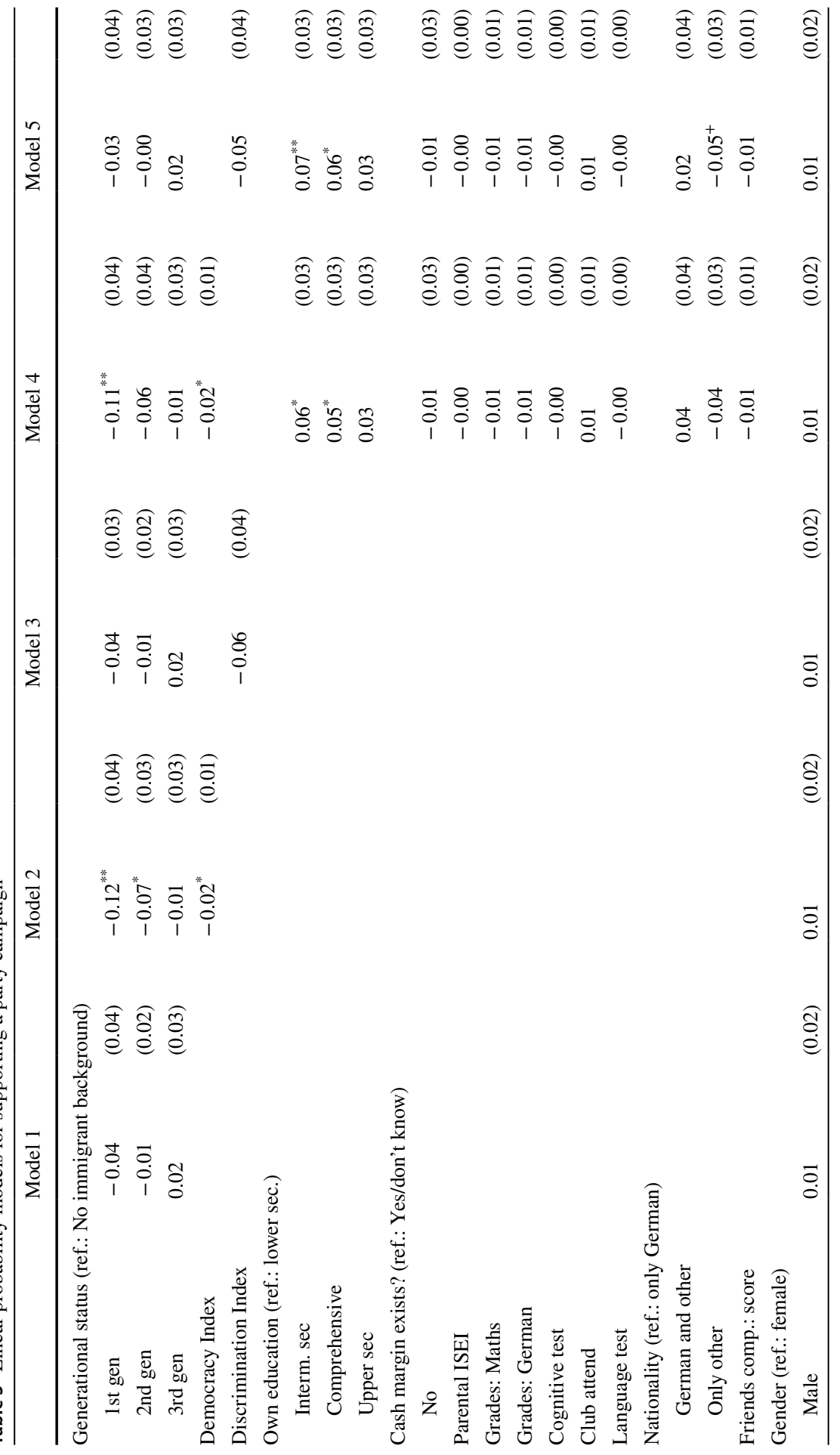




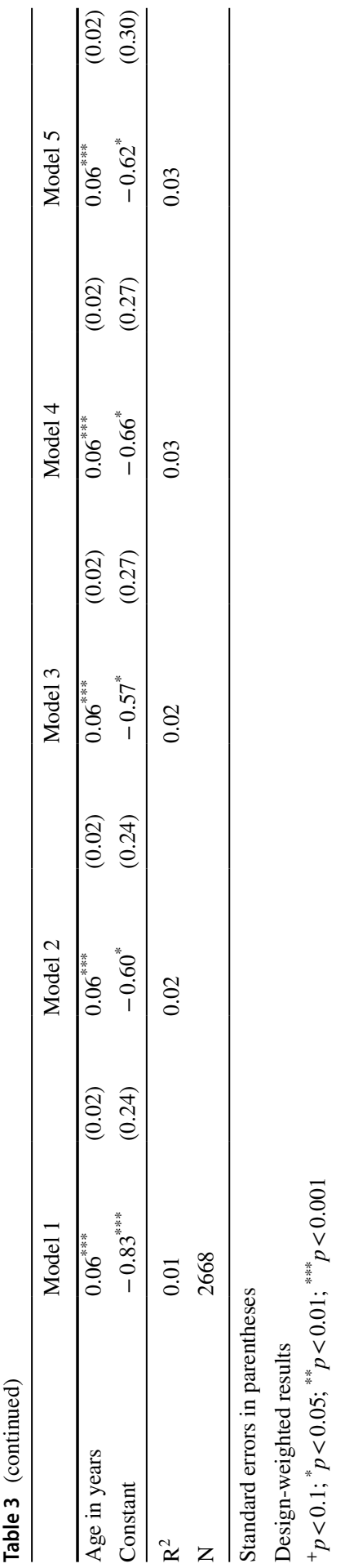




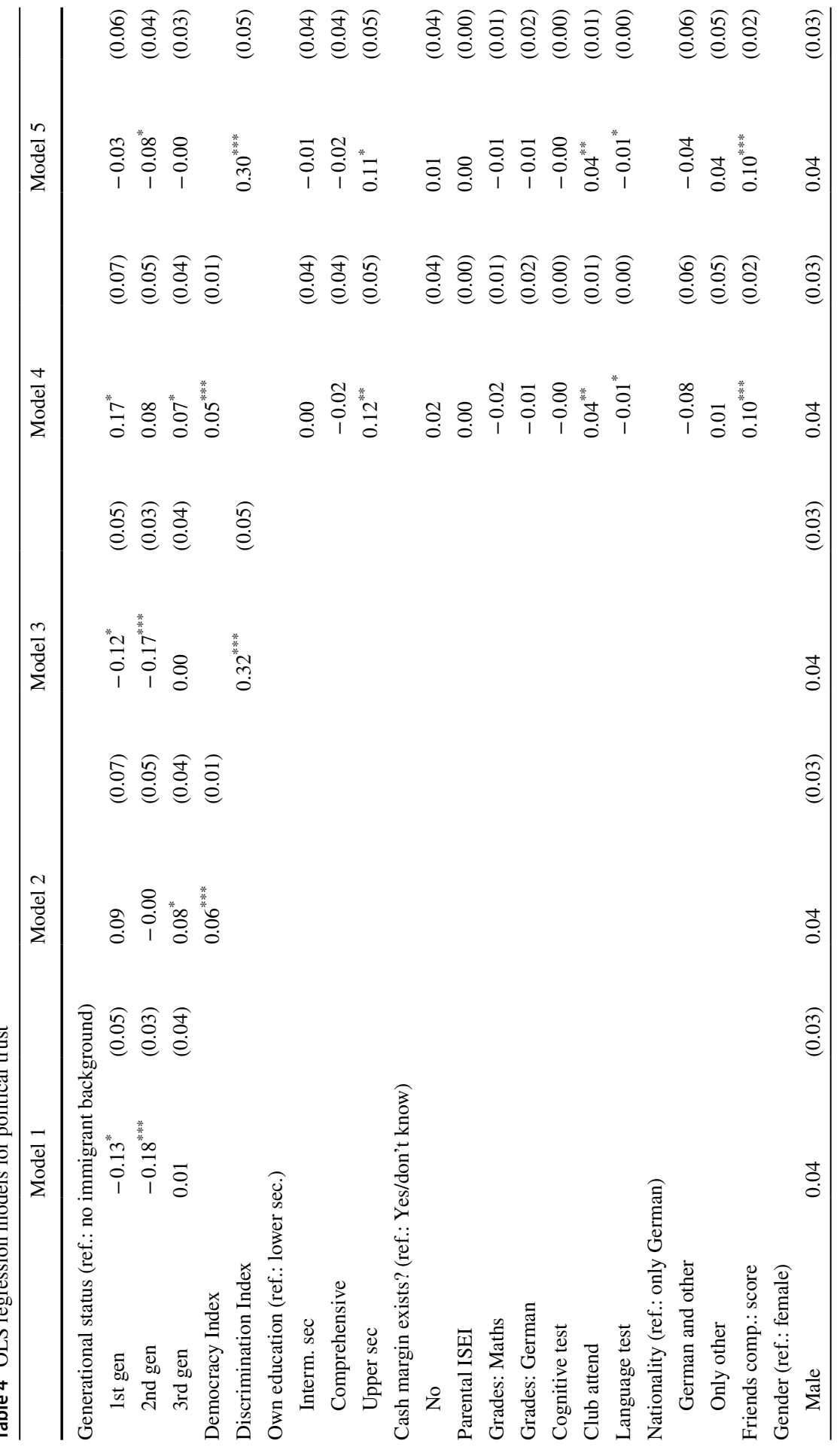




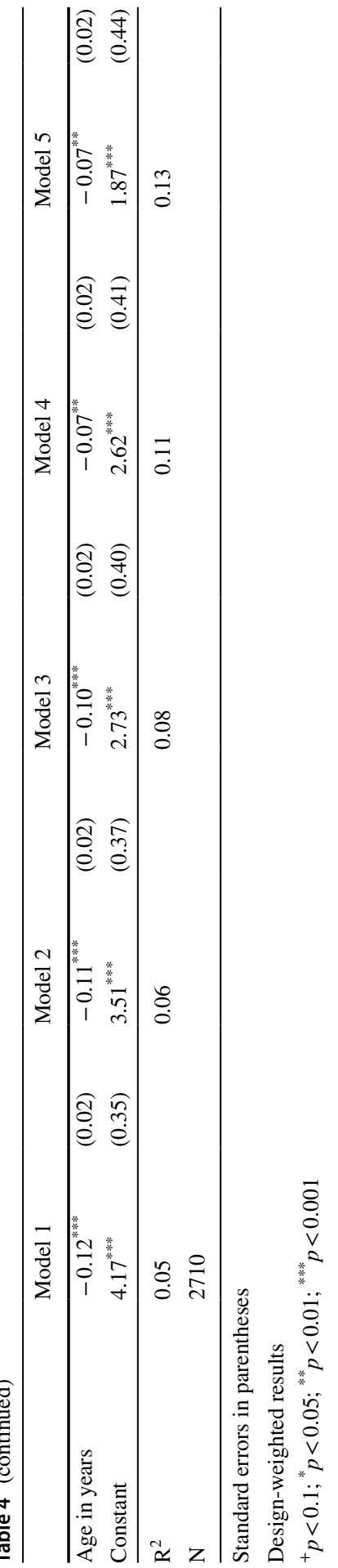




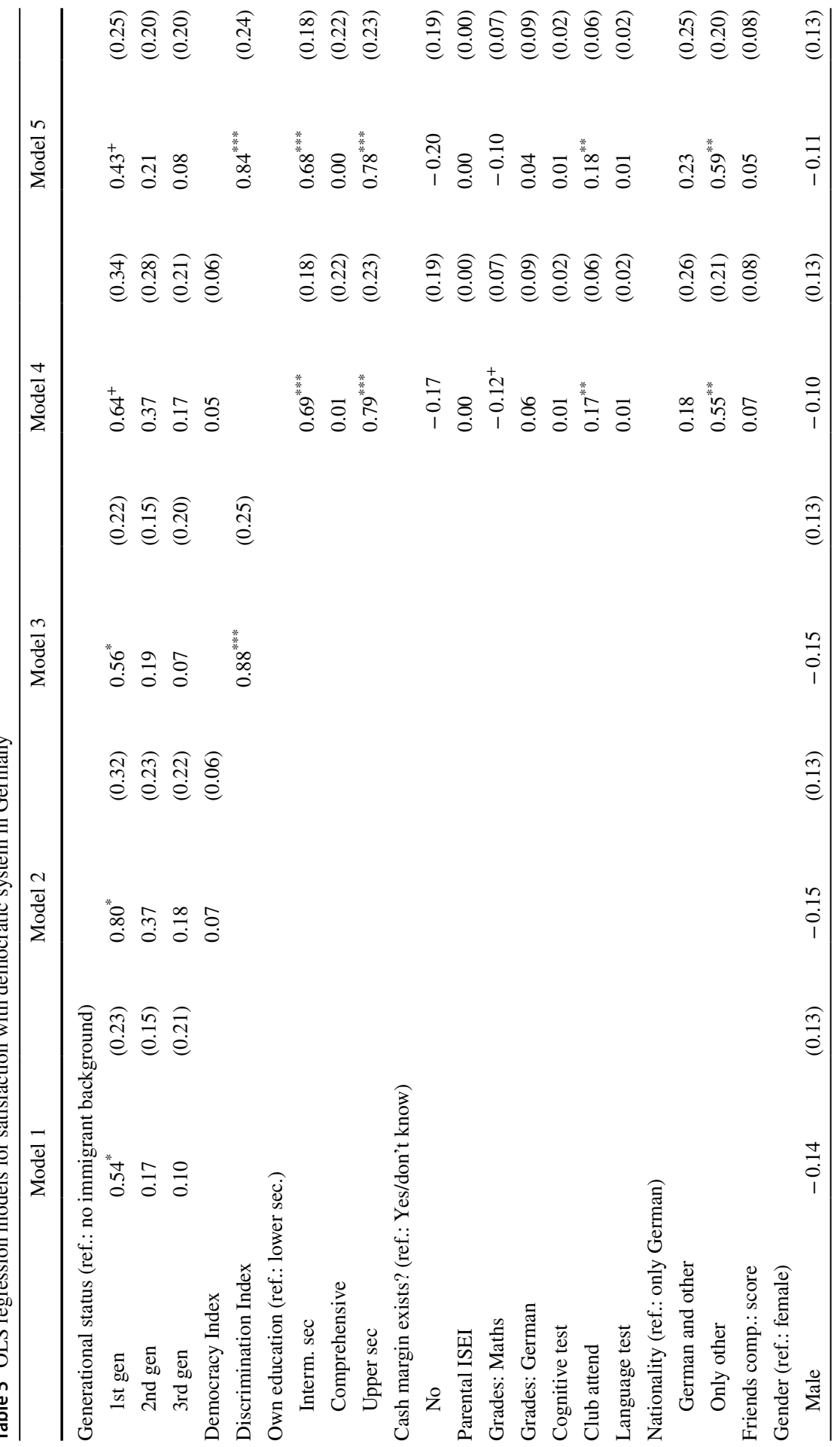




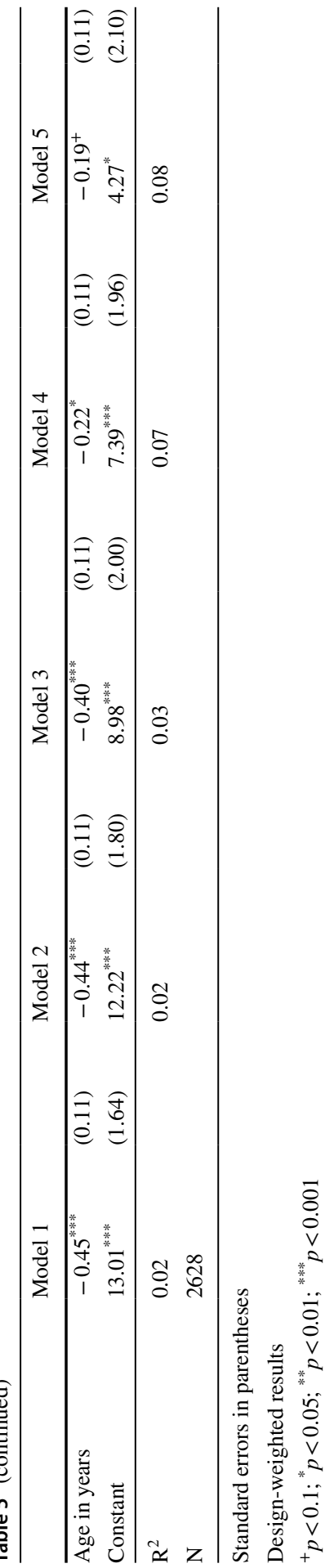


the attitudinal dimension than for the behavioural dimension. Here, immigrants who stem from more liberal societies and have experienced less discrimination in everyday life are more satisfied with the German democratic system and have higher levels of political and institutionalised trust, which also holds true when considering several other individual-level characteristics (models 4 and 5 in Tables 4 and 5).

These results remain stable when we restrict our analyses to respondents from the first and second generation (see Tables 7, 8, 9, and 10 in the Appendix). Therefore, the results are not driven by respondents without an immigrant background and their scores for Germany on the Democracy Index.

One limitation is that we do not assess the kind of political action respondents take. For example, the mobilising effect of stemming from a highly authoritarian country may simply be due to the fact that those respondents are more likely to follow some kind of anti-system-related activities. Unfortunately, we have no information about the type of demonstrations respondents attend. However, the political and social integration module of the CILS4EU data provides information on the vote intention of the respondents. In the following analyses, we therefore use only the respondents who intended to vote for a centrist party and exclude all those who intend to vote for the far left or far right. Table 6 shows the regression coefficients for the same models as in Table 2. As can be seen, the results remain stable. The mobilisation effect of being socialised in a less liberal regime is therefore not associated with higher levels of anti-democratic actions (the same holds true when focusing only on immigrants; results available in Table 11 in the Appendix).

\section{Discussion}

This study asked whether adolescents with and without an immigrant background differ in their level of political integration on the behavioural and attitudinal dimension. Furthermore, we asked whether (children of) immigrants differ in their level of political integration depending on the level of authoritarianism of their country of origin. Finally, we assessed whether discrimination experiences in the receiving context play a role and contribute to differences in political integration.

The results show that differences between adolescents with and without an immigrant background are rather small and only to the disadvantage of immigrant youth for political trust. In contrast, we find positive effects with respect to satisfaction with democracy in Germany, but only for the first generation. The influence of the level of authoritarianism on political integration is dependent on the dimension under study: while there are positive effects on the behavioural dimension, respondents stemming from more authoritarian regimes show lower levels of political integration on the attitudinal dimension (cf. Bilodeau et al., 2010 for similar results when differentiating between electoral activities [behaviour] and support for democracy [attitudes]). These effects are independent of individual characteristics.

A very similar picture can be observed when looking at the role of perceived discrimination in the receiving context: while we find a mobilising effect on the behavioural dimension, 


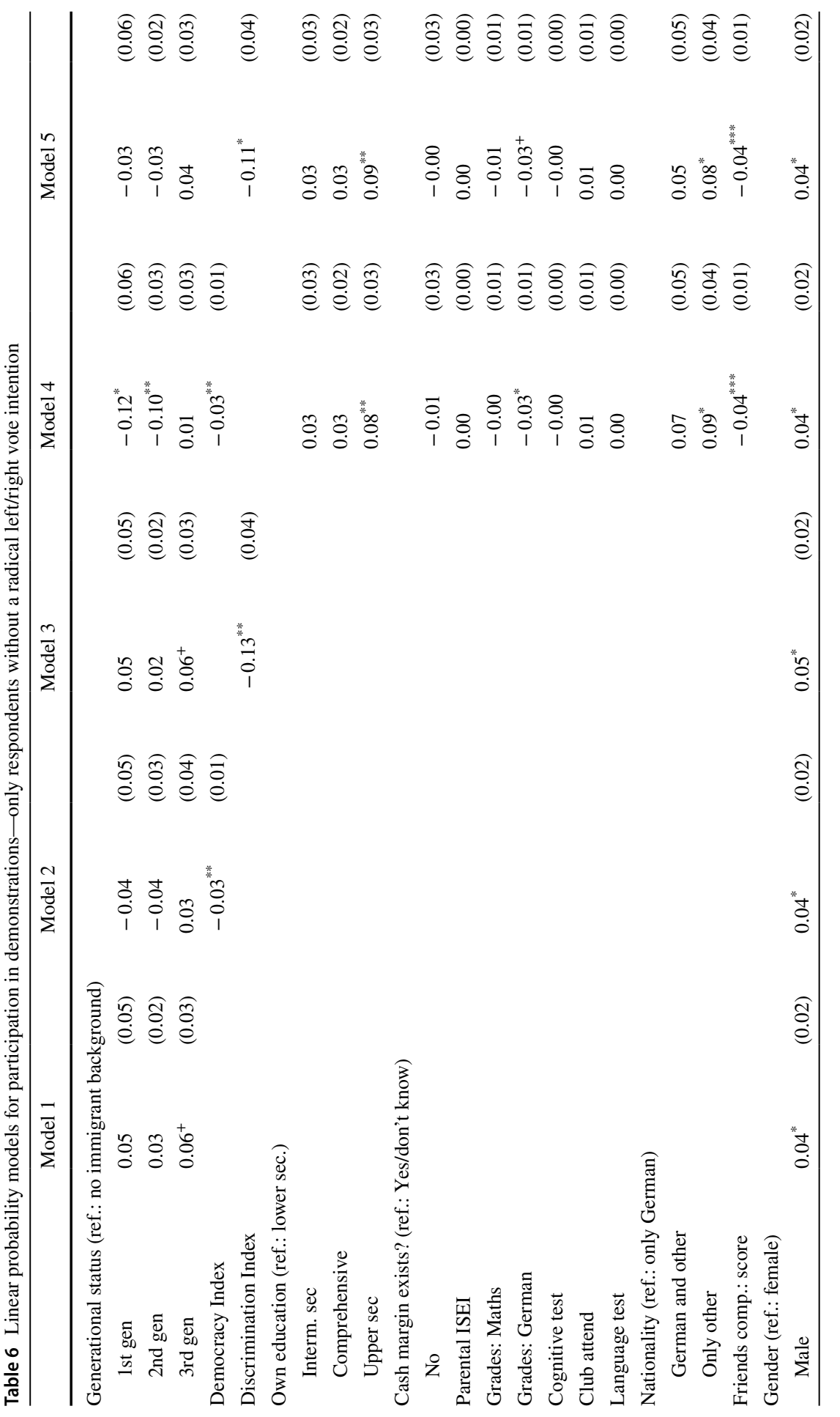




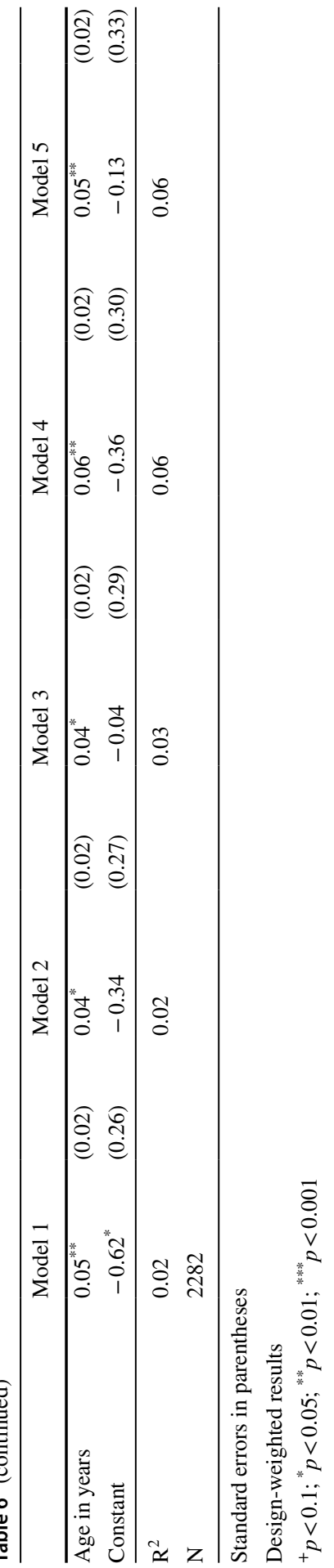

글 Springer 
and here especially for participation in demonstrations, we find lower levels on the attitudinal dimension. Political or institutionalised trust as well as satisfaction with the democratic system in Germany is lower when respondents experienced more discrimination in their everyday life.

Our results suggest that it is not per se negative for the political integration of immigrants into the host societies if they come from socio-politically less liberal societies. Immigrants from less liberal societies may nevertheless be politically active, although their experiences in the sending countries may affect their political attitudes, e.g. with respect to trust in political institutions. However, as we have shown, not only the conditions in the sending countries are important. Although perceived discrimination may mobilise immigrants to take political action, e.g. with the aim of reducing the inequalities by which they are affected, such experiences may also affect trust in political institutions and can therefore pose a challenge to the cohesion of a society as a whole. This is yet another reason to increase the efforts to reduce discrimination and unequal treatment of people based on their ethnic origin and other ascribed characteristics.

Given these clear differences between attitudes and behaviour, it should be noted that the aims and contents of the behaviours studied may not always be considered 'positive' for the political integration of immigrants. For example, participating in demonstrations may not necessarily be regarded as a positive form of political participation, especially when these demonstrations aim to implement non-democratic elements in a political regime (e.g. protest movements on the extreme left or right, claims for death penalty). The same holds true for support of undemocratic parties and campaigns or for involvement in political discussions with left- or right-wing extremist content. Unfortunately, we do not have information about the specific objectives of these different forms of political action. However, when considering only the political participation of the respondents who indicate to vote for a moderate party and excluding all those intending to vote for a far-left or a far-right party, the reported results remain constant and stable.

As the results show, it is important to differentiate between different forms of political integration and especially between the behavioural and attitudinal dimension. These differential results are in line with earlier findings, in which mobilisation effects are reported regarding the political participation of immigrants, and here especially in nonconventional forms, such as the participation in demonstrations; other authors report that discrimination may lead to a reduced confidence in political institutions (Röder and Mühlau, 2011) and is therefore likely to reduce political trust and satisfaction with the democratic system. Regarding future research, we recommend to take such differential effects according to the dimension of political integration into account.

A further limitation relates to the issue of selectivity of migration to specific receiving contexts: the high levels of political participation among respondents from more authoritarian countries could be due to the fact that politically active individuals are more likely to leave their country of origin. Such selectivity could also apply to the choice of the receiving context: for example, politically active immigrants might choose Germany as a destination, while less political active immigrants might choose other destinations. Therefore, international comparative research is needed to further address this issue.

Although the study did not focus on members of the recent wave of migration to Europe in general and to Germany in particular since 2015, it was nevertheless possible to study patterns of political participation of both recent and longer-residing immigrants from different types of regime. The results refute the assumption 
that immigrants from less liberal and less democratic countries are reluctant to participate in different forms of political action. Instead, a more differentiated picture emerges, and the results suggest that it is the time spent in the receiving society that contributes to assimilating the levels of political integration-if differences persist at all in the beginning. However, it remains an open question whether and how these results may be transferred to refugees and migrants from the recent migration wave, as these may differ with respect to their socioeconomic background and their reasons for leaving their sending countries. Especially for those cases, not only intergenerational changes in political integration but also intragenerational changes may be an important topic to study, however requiring high-quality longitudinal data.

\section{Appendix}

Table 7 Linear probability models for Participation in demonstrations; only immigrants of 1st and 2nd generation

\begin{tabular}{|c|c|c|c|c|c|c|c|c|c|c|}
\hline & \multicolumn{2}{|l|}{ Model 1} & \multicolumn{2}{|l|}{ Model 2} & \multicolumn{2}{|l|}{ Model 3} & \multicolumn{2}{|l|}{ Model 4} & \multicolumn{2}{|l|}{ Model 5} \\
\hline \multicolumn{11}{|c|}{ Generational status (ref.: 1st gen.) } \\
\hline 2nd gen & -0.02 & $(0.05)$ & -0.00 & $(0.05)$ & -0.02 & $(0.05)$ & 0.01 & $(0.05)$ & -0.01 & $(0.05)$ \\
\hline Democracy Index & & & $-0.02^{* *}$ & $(0.01)$ & & & $-0.02^{*}$ & $(0.01)$ & & \\
\hline Discrimination Index & & & & & $-0.21^{* * *}$ & $(0.08)$ & & & $-0.19^{* *}$ & $(0.07)$ \\
\hline \multicolumn{11}{|c|}{ Own education (ref.: lower sec.) } \\
\hline Interm. sec & & & & & & & 0.07 & $(0.04)$ & $0.07^{+}$ & $(0.04)$ \\
\hline Comprehensive & & & & & & & -0.01 & $(0.04)$ & -0.00 & $(0.04)$ \\
\hline Upper sec & & & & & & & 0.05 & $(0.05)$ & 0.06 & $(0.05)$ \\
\hline \multicolumn{11}{|c|}{ Cash margin exists? (ref.: Yes/don't know) } \\
\hline No & & & & & & & -0.02 & $(0.04)$ & -0.02 & $(0.04)$ \\
\hline Parental ISEI & & & & & & & -0.00 & $(0.00)$ & -0.00 & $(0.00)$ \\
\hline Grades: Maths & & & & & & & -0.00 & $(0.02)$ & -0.01 & $(0.02)$ \\
\hline Grades: German & & & & & & & $-0.05^{+}$ & $(0.03)$ & -0.04 & $(0.03)$ \\
\hline Cognitive test & & & & & & & -0.01 & $(0.00)$ & -0.01 & $(0.00)$ \\
\hline Club attend & & & & & & & $0.02^{+}$ & $(0.01)$ & 0.02 & $(0.01)$ \\
\hline Language test & & & & & & & 0.00 & $(0.00)$ & 0.00 & $(0.00)$ \\
\hline \multicolumn{11}{|c|}{ Nationality (ref.: only German) } \\
\hline German and other & & & & & & & 0.02 & $(0.05)$ & -0.00 & $(0.05)$ \\
\hline Only other & & & & & & & $0.07^{+}$ & $(0.04)$ & 0.05 & $(0.04)$ \\
\hline Friends comp.: score & & & & & & & $-0.04^{* *}$ & $(0.02)$ & $-0.04^{* *}$ & $(0.01)$ \\
\hline \multicolumn{11}{|l|}{ Gender (ref.: female) } \\
\hline Male & -0.00 & $(0.03)$ & 0.00 & $(0.03)$ & 0.01 & $(0.03)$ & -0.00 & $(0.04)$ & 0.01 & $(0.04)$ \\
\hline Age in years & 0.02 & $(0.03)$ & 0.01 & $(0.03)$ & 0.00 & $(0.03)$ & 0.02 & $(0.03)$ & 0.01 & $(0.03)$ \\
\hline Constant & -0.16 & $(0.47)$ & 0.10 & $(0.44)$ & $0.88^{+}$ & $(0.46)$ & 0.20 & $(0.45)$ & $0.94^{*}$ & $(0.45)$ \\
\hline $\mathrm{R}^{2}$ & 0.02 & & 0.02 & & 0.04 & & 0.06 & & 0.08 & \\
\hline $\mathrm{N}$ & 1151 & & & & & & & & & \\
\hline
\end{tabular}

Standard errors in parentheses

Design-weighted results

${ }^{+} p<0.1 ;{ }^{*} p<0.05 ;{ }^{* *} p<0.01 ;{ }^{* * *} p<0.001$ 


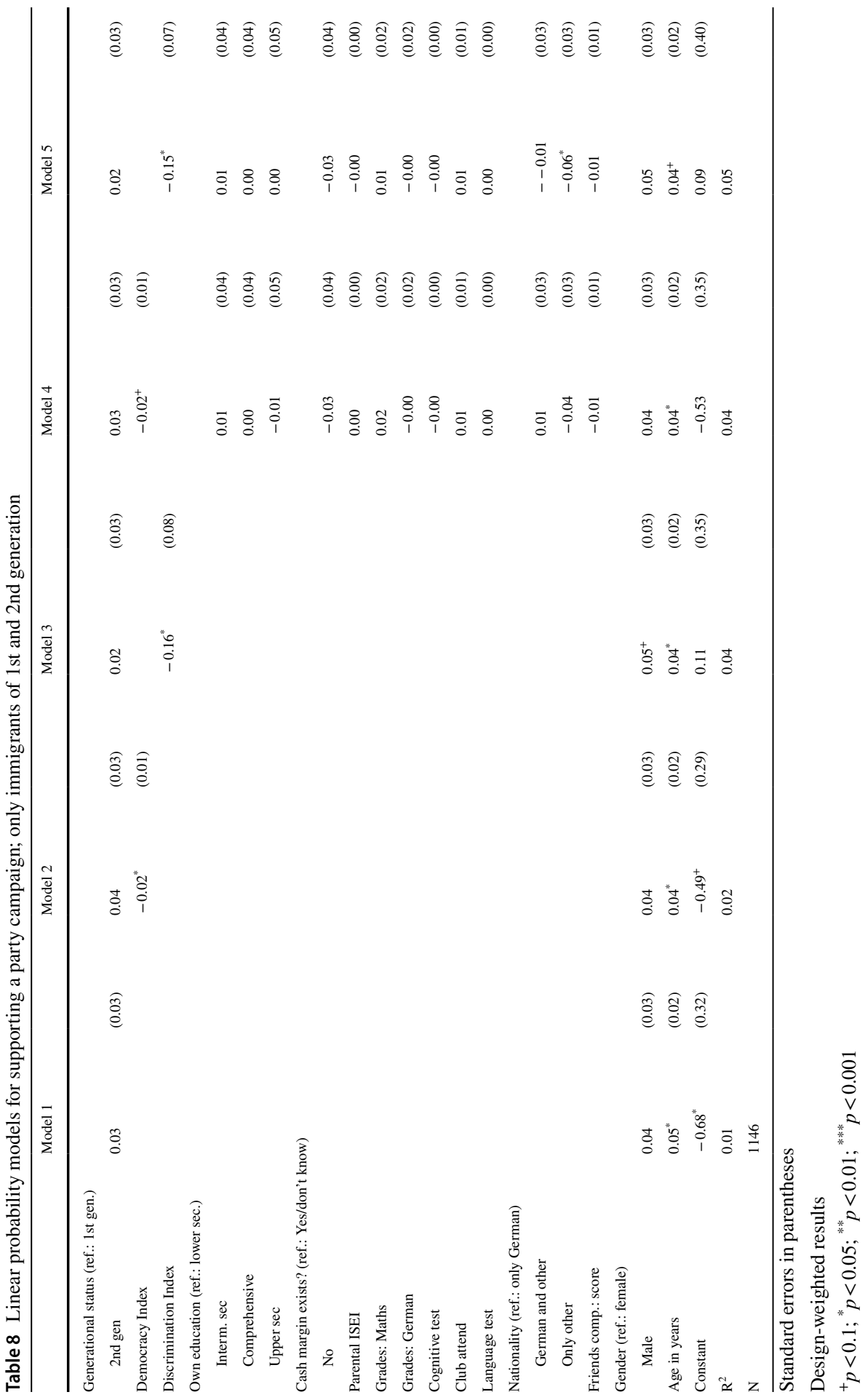




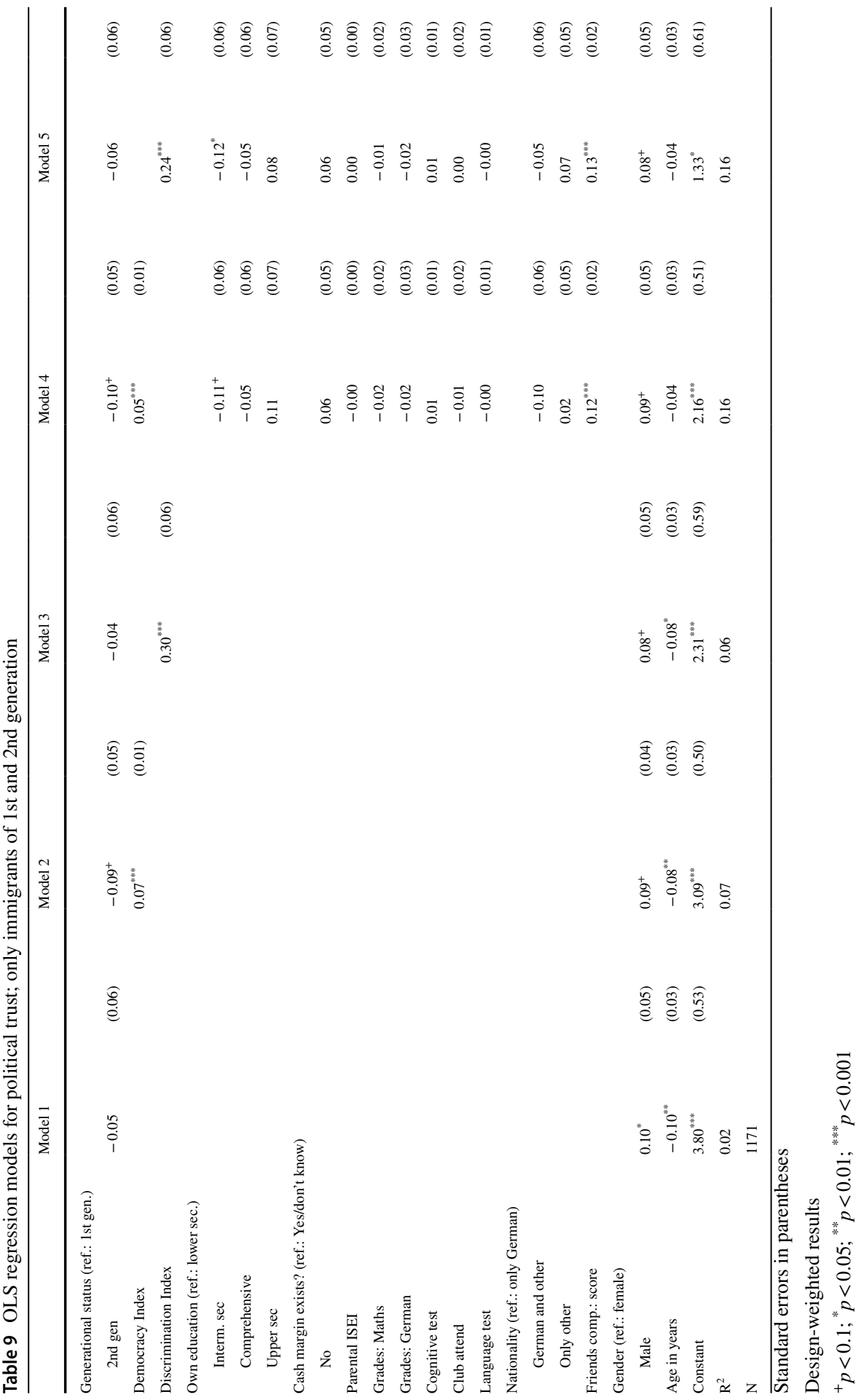




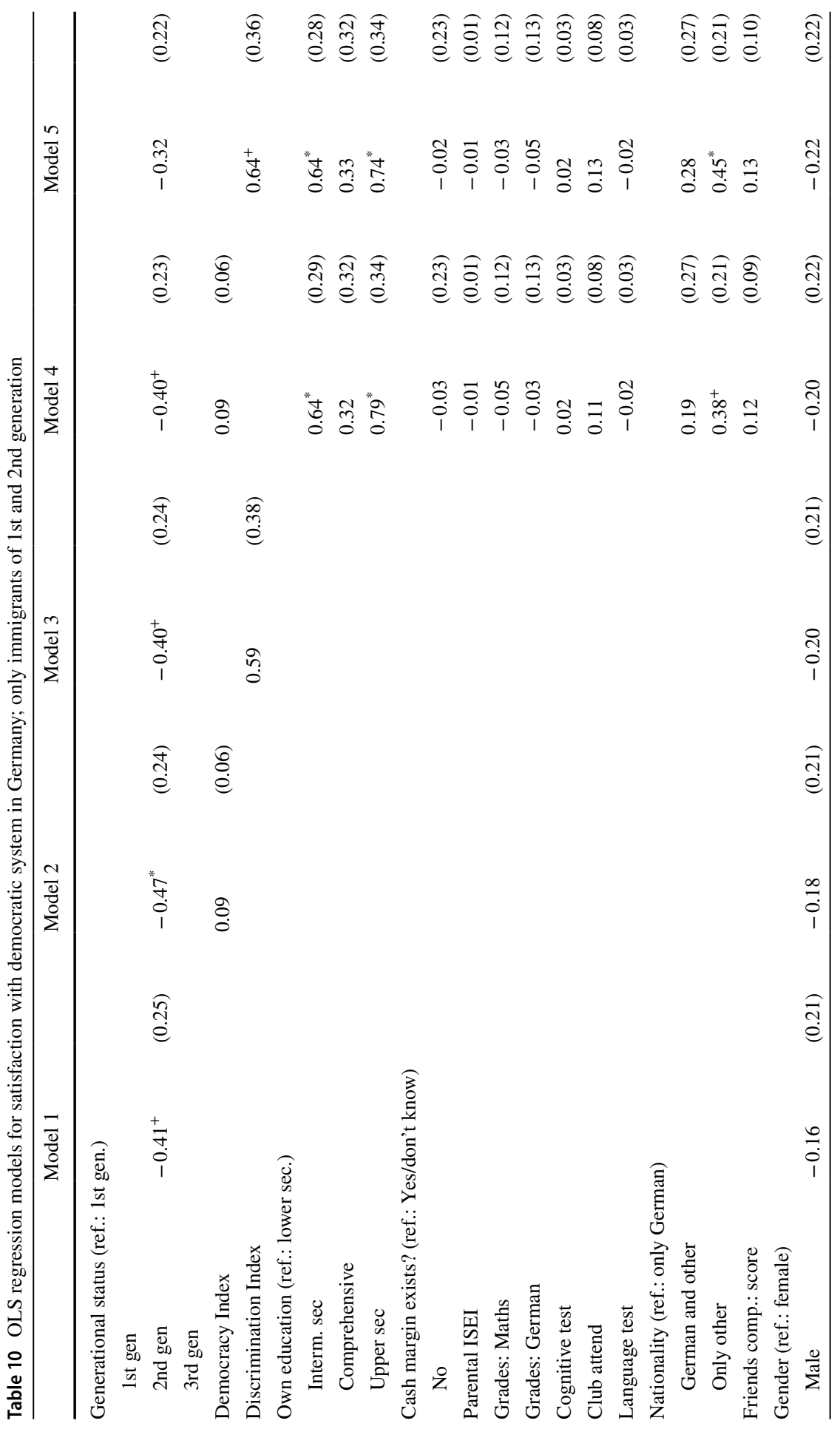




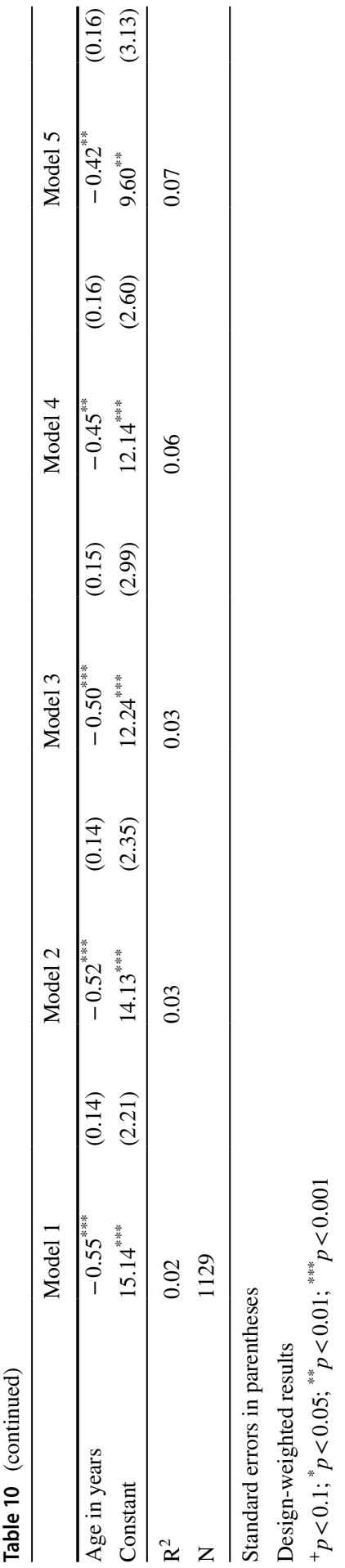

글 Springer 


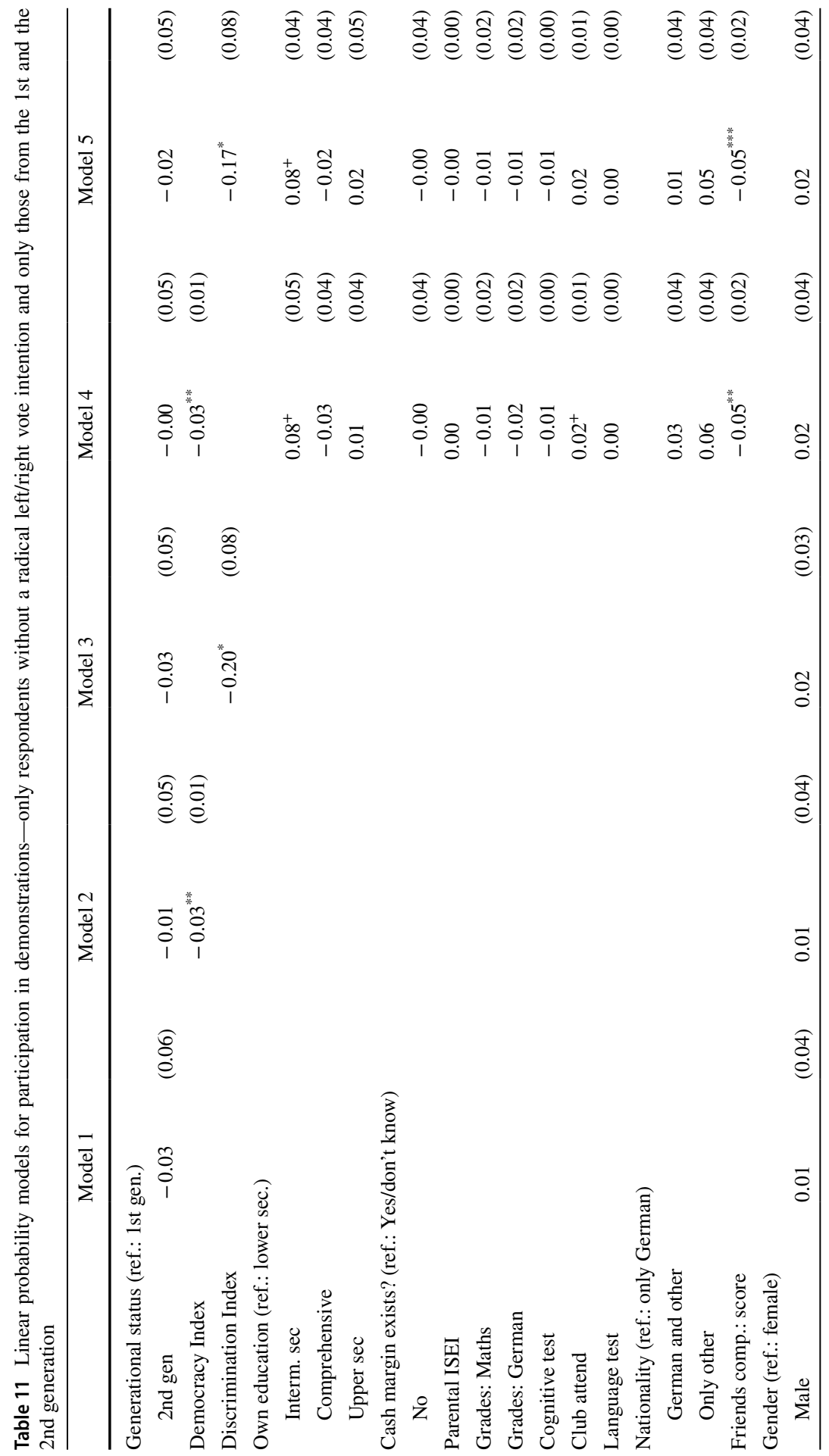




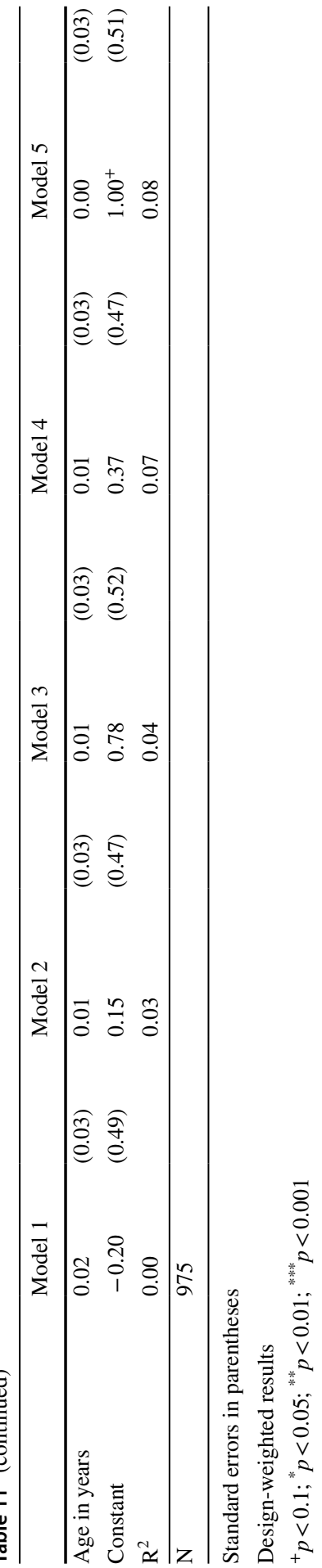

글 Springer 
Funding Open Access funding enabled and organized by Projekt DEAL.

Open Access This article is licensed under a Creative Commons Attribution 4.0 International License, which permits use, sharing, adaptation, distribution and reproduction in any medium or format, as long as you give appropriate credit to the original author(s) and the source, provide a link to the Creative Commons licence, and indicate if changes were made. The images or other third party material in this article are included in the article's Creative Commons licence, unless indicated otherwise in a credit line to the material. If material is not included in the article's Creative Commons licence and your intended use is not permitted by statutory regulation or exceeds the permitted use, you will need to obtain permission directly from the copyright holder. To view a copy of this licence, visit http://creativecommons.org/licen ses/by/4.0/.

\section{References}

Adida, C.L., Laitin, D.D. \& Valfort, M.-A. (2014). Muslims in France: identifying a discriminatory equilibrium. Journal of Population Economics, 27(4), 1039-1086. https://doi.org/10.1007/ s00148-014-0512-1

Andritzky, J., Bodo A., Christofzik, D. I. and Schmidt, C. M. (2016) Influx of refugees: Integration as a key challenge (no. 09/2016). Working Paper 09/2016. German Council of Economic Experts.

Barnes, S. H., Kaase, M., Allerbeck, K. R., Farah, B. G., Heunks, F., Ronald Inglehart, M., Jennings, K., Klingemann, H. D., Marsh, A., \& Rosenmayr, L. (1979). Political action: Mass participation in five Western democracies. Sage.

Bartram, D. (2019). The UK citizenship process: Political integration or marginalization? Sociology, 53(4), 671-688

Bevelander, P., \& Pendakur, R. (2011). Voting and social inclusion in Sweden. International Migration, 49(4), 67-92

Bilodeau, A. (2008). Immigrants' voice through protest politics in Canada and Australia: Assessing the impact of pre-migration political repression. Journal of Ethnic and Migration Studies, 34(6), 975-1002

Bilodeau, A., McAllister, I., \& Kanji, M. (2010). Adaptation to democracy among immigrants in Australia. International Political Science Review, 31(2), 141-165

Brady, H. E., Verba, S., \& Schlozman, K. L. (1995). Beyond SES: A resource model of political participation. American Political Science Review, 89(2), 271-294

Cho, W. K. T., Gimpel, J. G., \& Wu, T. (2006). Clarifying the role of SES in political participation: Policy threat and Arab American mobilization. Journal of Politics, 68(4), 977-991.

CILS4EU. (2016a). Children of Immigrants Longitudinal Survey in Four European Countries. Technical Report. Wave 1 - 2010/2011, v1.2.0. Mannheim University.

CILS4EU. (2016b). Children of Immigrants Longitudinal Survey in Four European Countries. Technical Report. Wave 2 - 2011/2012, v2.3.0. Mannheim University.

CILS4EU. (2016c). Children of Immigrants Longitudinal Survey in Four European Countries. Technical Report. Wave 3 - 2012/2013, v3.2.0. Mannheim University.

Dollmann, J., Konstanze, J. and Kalter, F. (2014). Examining the diversity of youth in Europe. A classification of generations and ethnic origins using CILS4EU data. Mannheimer Zentrum für Europäische Sozialforschung: Working Paper 156. Universität Mannheim.

Economist Intelligence Unit. (2015). Democracy Index 2014. Accessed 4 Dec 2019; https://dataspace.princ eton.edu/jspui/bitstream/88435/dsp01cf95jd932/1/Democracy-index-2014.pdf.

Eggert, N., \& Giugni, M. (2010). Does associational involvement spur political integration? Political interest and participation of three immigrant groups in Zurich. Swiss Political Science Review, 16(2), 175-210

Esser, H. (2015) 'Early conditions of political participation and civic integration of immigrant children' In: Poguntke, T., Roßteutscher, S., Schmitt-Beck, R. and Zmerli, S. (eds): Citizenship and democracy in an era of crisis: Essays in honour of Jan W. van Deth, pp. 115-134. Routledge.

Fleischmann, F., Phalet, K., \& Klein, O. (2011). Religious identification and politicization in the face of discrimination: Support for political Islam and political action among the Turkish and Moroccan second generation in Europe. British Journal of Social Psychology, 50(4), 628-648 
Galston, W. A. (2001). Political knowledge, political engagement, and civic education. Annual Review of Political Science, 4(1), 217-234

Heath, A. F., Rothon, C., \& Kilpi, E. (2008). The second generation in Western Europe: Education, unemployment, and occupational attainment. Annual Review of Sociology, 34, 211-235

Heller, K. A. and Perleth, V. (2000). Kognitiver Fähigkeitstest für 4.-12 Klassen, Revision (KFT 4-12+ R). Hogrefe.

Horr, A., Hunkler, C., \& Kroneberg, C. (2018). Ethnic discrimination in the German housing market: A field experiment on the underlying mechanisms. Zeitschrift Für Soziologie, 47(2), 134-146

Jaggers, K., \& Gurr, T. R. (1995). Tracking democracy's third wave with the polity III data. Journal of Peace Research, 32(4), 469-482

Jennings, M. K., Stoker, L., \& Bowers, J. (2009). Politics across generations: Family transmission reexamined. The Journal of Politics, 71(3), 782-799

Just, A., \& Anderson, C. J. (2012). Immigrants, citizenship and political action in Europe'. British Journal of Political Science, 42(3), 481-509

Just, A., \& Anderson, C. J. (2014). Opinion climates and immigrant political action: A cross-national study of 25 European democracies. Comparative Political Studies, 47(7), 935-965

Kaas, L., \& Manger, C. (2012). Ethnic discrimination in Germany's labour market: A field experiment. German Economic Review, 13(1), 1-20

Kalter, F. (2016). 'Social network analysis in the study of ethnic inequalities', Emerging trends in the social and behavioral sciences: An interdisciplinary, searchable, and linkable resource 1-15.

Kalter, F., Heath, A. F., Hewstone, M., Jonsson, J. O., Kalmijn, M., Kogan, I. and van Tubergen, F. (2016a). Children of Immigrants Longitudinal Survey in Four European Countries (CILS4EU) - Full version. Data file for on-site use. GESIS Data Archive, Cologne, ZA5353 Data file Version 1.2.0. https://doi. org/10.4232/cils4eu.5353.1.2.0.

Kalter, F., Heath, A. F., Hewstone, M., Jonsson, J. O., Kalmijn, M., Kogan, I. and van Tubergen, F. (2016b). Children of Immigrants Longitudinal Survey in Four European Countries (CILS4EU) - Full version. Data file for on-site use. GESIS Data Archive, Cologne, ZA5353 Data file Version 2.3.0. https://doi. org/10.4232/cils4eu.5353.2.3.0.

Kalter, F., Heath, A. F., Hewstone, M., Jonsson, J. O., Kalmijn, M., Kogan, I. and van Tubergen, F. (2016c). Children of Immigrants Longitudinal Survey in Four European Countries (CILS4EU) - Full version. Data file for on-site use. GESIS Data Archive, Cologne, ZA5353 Data file Version 3.2.0. https://doi. org/10.4232/cils4eu.5353.3.2.0.

Kalter, F., Kogan, I. and Dollmann, J. (2017). Children of Immigrants Longitudinal Survey in Four European Countries - Germany (CILS4EU-DE) - Full Version. Data file for on-site use. GESIS Data Archive, Cologne, ZA6655 Data file Version 2.0.0.

Kalter, F., Kogan, I., \& Dollmann, J. (2019). Studying integration from adolescence to early adulthood: Design, content, and research potential of the CILS4EU-DE data. European Sociological Review, 35(2), 280-297

Kristen, C., \& Granato, N. (2007). The educational attainment of the second generation in Germany: Social origins and ethnic inequality. Ethnicities, 7, 343-366

Leighley, J. E., \& Vedlitz, A. (1999). Race, ethnicity, and political participation: Competing models and contrasting explanations. The Journal of Politics, 61(4), 1092-1114

Lijphart, A. (1997). Unequal participation: Democracy's unresolved dilemma. Presidential Address, American Political Science Association, 1996. American Political Science Review, 91(1), 1-14

Liebe, U. and Beyer, H. (2020). 'Examining discrimination in everyday life: A stated choice experiment on racism in the sharing economy.' Journal of Ethnic and Migration Studies. https://doi.org/10.1080/ 1369183X.2019.1710118

Logan, J. R., Darrah, J., \& Sookhee, Oh. (2012). The impact of race and ethnicity, immigration and political context on participation in American electoral politics. Social Forces, 90(3), 993-1022

Martinez, L. M. (2005). Yes we can: Latino participation in unconventional politics. Social Forces, 84(1), 135-155

Martiniello, M. (2006). 'Political participation, mobilisation and representation of immigrants and their offspring in Europe'. In R. Bauböck (ed.) Migration and citizenship. Legal status, rights and political participation, pp. 83-105. Amsterdam University Press.

McFarland, D. A., \& Thomas, R. J. (2006). Bowling young: How youth voluntary associations influence adult political participation. American Sociological Review, 71(3), 401-425

Miller, J. M., \& Krosnick, J. (2004). Threat as a motivator of political activism: A field experiment. Political Psychology, 25(4), 507-523 
Mood, C. (2010). Logistic regression: Why we cannot do what we think we can do, and what we can do about it. European Sociological Review, 26(1), 67-82

Mustillo, S. (2012). The effects of auxiliary variables on coefficient bias and efficiency in multiple imputation. Sociological Methods and Research, 41(2), 335-361

Olszenka, N., Sauter, L., Bengert, E., Konstanze J. and Kruse, H. (2016). Children of Immigrants Longitudinal Survey in Four European Countries - Germany. Technical Report. Wave 4 - 2014, v1.0.0. Mannheim University.

Ramakrishnan, S. K. (2005). Democracy in immigrant America: Changing demographics and political participation. Stanford University Press.

Ramakrishnan, S. K., \& Espenshade, T. J. (2001). Immigrant incorporation and political participation in the United States. International Migration Review, 35(3), 870-909

Röder, A. \& Mühlau, P. (2011). Discrimination, exclusion and immigrants' confidence in public institutions in Europe. European Societies, 13(4), 535-557. https://doi.org/10.1080/14616696.2011.597869

Rooij, De., \& Eline, A. (2012). Patterns of immigrant political participation: Explaining differences in types of political participation between immigrants and the majority population in Western Europe. European Sociological Review, 28(4), 455-481

Royston, P. (2004). Multiple imputation of missing values. The Stata Journal, 4(3), 227-241

Sauter, L., Olszenka, N., Bengert, E., Konstanze J., and Kruse, H. (2017). Children of Immigrants Longitudinal Survey in Four European Countries - Germany. Technical Report. Wave 5 - 2015, v2.0.0. Mannheim University.

Schildkraut, D. J. (2005). The rise and fall of political engagement among Latinos: The role of identity and perceptions of discrimination. Political Behavior, 27(3), 285-312

Semyonov, M., Raijman, R., Tov, A. Y., \& Schmidt, P. (2004). Population size, perceived threat, and exclusion: A multiple-indicators analysis of attitudes toward foreigners in Germany. Social Science Research, 33(4), 681-701

Shingles, R. D. (1981). Black consciousness and political participation: The missing link. American Political Science Review, 75(1), 76-91

Tillie, J. (2004). Social capital of organisations and their members: Explaining the political integration of immigrants in Amsterdam. Journal of Ethnic and Migration Studies, 30(3), 529-541

Uslaner, E. M., \& Conley, R. S. (2003). Civic engagement and particularized trust: The ties that bind people to their ethnic communities. American Politics Research, 31(4), 331-360

Verba, S., \& Nie, N. H. (1987). Participation in America: Political democracy and social equality. University of Chicago Press.

Verba, S., Schlozman, K. L., \& Brady, H. E. (1995). Voice and equality: Civic voluntarism in American politics. Harvard University Press.

Verba, S., Schlozman, K. L., Brady, H. E., \& Nie, N. H. (1993). Race, ethnicity and political resources: Participation in the United States. British Journal of Political Science, 23(4), 453-497

Voicu, B., \& Comşa, M. (2014). Immigrants' participation in voting: Exposure, resilience, and transferability. Journal of Ethnic and Migration Studies, 40(10), 1572-1592

Von Hippel, P. T. (2007). Regression with missing Ys: An improved strategy for analyzing multiply imputed data. Sociological Methodology, 37(1), 83-117

Von Hippel, P. T. (2018). 'How many imputations do you need? A two-stage calculation using a quadratic rule'. Sociological Methods and Research. https://doi.org/10.1177/0049124117747303

Weiß, R. H. (1998). Grundintelligenztest Skala 2 (CFT 20). Hogrefe.

White, S., Nevitte, N., Blais, A., Gidengil, E., \& Fournier, P. (2008). The political resocialization of immigrants: Resistance or lifelong learning? Political Research Quarterly, 61(2), 268-281

Wong, J., \& Tseng, V. (2008). Political socialisation in immigrant families: Challenging top-down parental socialisation models. Journal of Ethnic and Migration Studies, 34(1), 151-168

Publisher's Note Springer Nature remains neutral with regard to jurisdictional claims in published maps and institutional affiliations. 